\title{
Post-harvest characterization of 'Prata' banana cultivar grown under different nitrogen and potassium fertilization
}

\author{
Edson Shigueaki Nomura ${ }^{1}$, Francine Lorena $\mathrm{Cuquel}^{2}$, Erval Rafael Damatto Junior ${ }^{1}$, \\ Daniela Peixoto Bezerra ${ }^{3}$, Ana Lúcia Borges ${ }^{4}$
}

\begin{abstract}
There are several banana cultivars resistant to Black Sigatoka disease and to Panama disease, but due to the lack of information regarding post-harvest characteristics, many are rejected in the market. Nitrogen and potassium fertilization may help to improve the sensory characteristics of ripe banana, but there is lack of studies on its effects on banana cultivation, especially those resistant to diseases. The aim of this study was to evaluate the post-harvest characteristics of 'PrataAnã', 'BRS Platina' and 'PA94-01' banana cultivars at four $\mathrm{N}$ and $\mathrm{K}_{2} \mathrm{O}$ fertilization levels (NK0: no fertilization, NK1: 175 and $285 \mathrm{~kg} \mathrm{ha}^{-1}$ year $^{-1}$, NK2: 350 and $570 \mathrm{~kg} \mathrm{ha}^{-1}$ year $^{-1}$, NK3: 525 and $855 \mathrm{~kg} \mathrm{ha}^{-1} \mathrm{year}^{-1}$, respectively) in three production cycles. It could be concluded that $\mathrm{N}$ and $\mathrm{K}$ doses adopted in this work did not influence the post-harvest physicochemical characteristics of 'Prata-Anã', 'BRS Platina' and 'PA94-01' banana cultivars. Regardless of N and K doses, 'PrataAnã', 'BRS Platina' and PA94-01' banana cultivars presented differences regarding post-harvest physicochemical characteristics. Production cycles did not influence the physical characteristics but differed in post-harvest chemical characteristics in 'Prata-Anã', 'BRS Platina' and 'PA94-01' banana cultivars.

Index terms: Musa spp.; banana; nutrition; acidity; ratio.

\section{Pós-colheita de cultivares de bananas tipo prata em níveis de adubação nitrogenada e potássica}

Corresponding author: edsonnomura@apta.sp.gov.br

Received: December 21, 2018 Accepted: July 03, 2019

Copyright: All the contents of this journal, except where otherwise noted, is licensed under a Creative Commons Attribution License.

\section{(cc) $\mathrm{EY}$}

\begin{abstract}
Resumo - Existem diversas cultivares de banana resistentes à Sigatoka-negra e Fusariose da bananeira; porém, pela falta de informações referentes às características de pós-colheita, muitas são rejeitadas no mercado. A adubação nitrogenada e potássica poderia auxiliar na melhoria das características sensoriais da banana madura; no entanto, pouco se sabe sobre os seus efeitos no cultivo de bananeira, principalmente as com resistência às doenças foliares. Objetivou-se avaliar as características pós-colheita de frutos das cultivares de bananeiras do tipo Prata (Prata-Anã, BRS Platina e PA94-01), em quatro níveis de adubação com N e K 2 (NK0: sem adubação; NK1: 175 e $285 \mathrm{~kg} \mathrm{ha}^{-1}$ ano $^{-1}$; NK2: 350 e $570 \mathrm{~kg} \mathrm{ha}^{-1}$ ano $^{-1}$; NK3: 525 e $855 \mathrm{~kg} \mathrm{ha}^{-1} \mathrm{ano}^{-1}$, respectivamente), em três ciclos de produção. Conclui-se que as doses de $\mathrm{N}$ e $\mathrm{K}$ adotados neste trabalho não influenciaram os caracteres físico-químicos da pós-colheita nas cultivares Prata-Anã, BRS Platina e PA94-01. Independentemente das doses de N e K, as cultivares de bananeiras Prata-Anã, BRS Platina e PA94-01 apresentaram diferenças entre si nos caracteres físico-químicos de pós-colheita. Os ciclos de produção não influenciaram os caracteres físicos, mas diferiram nos químicos, nas cultivares de bananeira Prata-Anã, BRS Platina e PA94-01.
\end{abstract}

Termos para indexação: Musa spp.; banana; nutrição; acidez; ratio. 


\section{Introduction}

The banana cultivars most commercially exploited in Brazil are 'Nanica', 'Nanicão', 'Grande Naine', 'Prata-anã', 'Ouro', 'Pacovan' and 'Maçã'; however, there is preference of the consumer market for 'Prata' and 'Nanica' cultivar. Among Prata type banana, 'PrataAnã' cultivar (AAB) stands out, with one of the largest production areas and market in Brazil. However, these cultivars do not present resistance to the two main fungal diseases that infect banana crops: Black Sigatoka disease (Mycosphaerella fijiensis Morelet) and Panama disease (Fusarium oxysporum $\mathrm{f}$. sp. cubense). On the other hand, the "EMBRAPA - Mandioca e Fruticultura" genetic breeding program has developed several banana cultivars such as 'BRS Platina' (PA42-44) and 'PA94-01', both tetraploid hybrids (AAAB) from 'Prata-Anã'; the first presenting resistance to Panama disease and the second to Black Sigatoka disease, and both with high yield and fruits similar in shape and size to those of 'Prata-Anã' cultivar, (NOMURA et al., 2013).

The adoption of tolerant or resistant cultivars is the most efficient method to deal with diseases, with lower or no use of chemical pesticides for their control, reducing fruit and environment contamination. Nevertheless, there is a rejection by the consumers for new bananas cultivars in Brazil, because it presents external and sensory differences of the fruits, partly due to the few studies related to the postharvest characteristics of banana cultivars resistant to diseases.

Nitrogen and potassium are the nutrients most absorbed by banana plants, influencing development, production and in the post-harvest characteristics, especially in the sensory characteristics of fruits, because they are responsible for the acidity index of pulp, playing a role parting the formation of sugars that will become starch (MOREIRA, 1999).

The physicochemical properties of banana may vary according to cultivar and agricultural procedures adopted for its cultivation, especially related to nutrition, since the fertilizer doses applied in pre-harvest directly affect the quality of bananas (SILVA et al., 1999). There are several studies on the development and production of desease-resistant banana cultivars, but their post-harvest characteristics have been little studied. In this context, the aim of this study was to evaluate the post-harvest characteristics of 'Prata' banana cultivars grown under different $\mathrm{N}$ and $\mathrm{K}$ doses in the edaphoclimatic conditions of the "Vale do Ribeira" region, SP.

\section{Material and methods}

Banana plantation was carried out at the Experimental farm of the "Agência Paulista de Tecnologia dos Agronegócios (APTA) - Polo Regional Vale do
Ribeira", located in the municipality of Pariquera-Açu-SP,

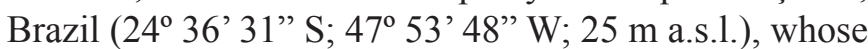
climate is classified as rainy tropical without dry season (Af), according to Köppen classification. Data recorded at the unit (2004 to 2014) show annual averages of maximum temperature of $26.8^{\circ} \mathrm{C}$, minimum temperature of $17.7^{\circ} \mathrm{C}$ and rainfall of $1,524.5 \mathrm{~mm}$.

'Prata' type cultivars were 'BRS Platina' (PA4244), 'PA94-01' and 'Prata-anã', which were evaluated during three production cycles (2013-2015). 'Prata-Anã' was considered the standard cultivar, because it is the traditional cultivar in the consumer market.

The experimental design was randomized blocks, and treatments were organized in a $3 \times 4$ factorial scheme (cultivars $\mathrm{x}$ fertilization doses) with subdivided plots in time (cycles).

Prior to the experiment installation, liming and fertilization were performed for both production cycles, with application of dolomitic limestone in total area, increasing the base saturation to $60 \%$ and magnesium content above $9.0 \mathrm{mmol} \mathrm{dm}^{-3}$, as recommended by Teixeira et al. (2014). Additionally, to achieve phosphorus requirements, $600 \mathrm{~kg} \mathrm{ha}^{-1}$ of simple superphosphate were applied in total area. Standard N and K fertilization (100\%) was calculated according to soil chemical analysis results, for an expected productivity from 40 to $50 \mathrm{tha}^{-1}$, according to Teixeira et al. (2014). In NK0 treatment, no N and $\mathrm{K}$ fertilization was performed; on NK1, $50 \%$ of standard N recommendation and was applied $\mathrm{K}\left(175 \mathrm{~kg} \mathrm{ha}^{-1} \mathrm{year}^{-1}\right.$ of N and $285 \mathrm{~kg} \mathrm{ha}^{-1}$ year $^{-1}$ of $\mathrm{K}_{2} \mathrm{O}$ ); in NK2, $100 \%$ of standard $\mathrm{N}$ and $\mathrm{K}$ recommendation was applied $\left(350 \mathrm{~kg} \mathrm{ha}^{-1}\right.$ of $\mathrm{N}$ and $570 \mathrm{~kg} \mathrm{ha}^{-1}$ year $^{-1}$ of $\mathrm{K}_{2} \mathrm{O}$ ) and in NK3, $150 \%$ of standard $\mathrm{N}$ and $\mathrm{K}$ recommendation was applied $\left(525 \mathrm{~kg} \mathrm{ha}^{-1}\right.$ of $\mathrm{N}$ and $855 \mathrm{~kg} \mathrm{ha}^{-1}$ year $^{-1}$ of $\mathrm{K}_{2} \mathrm{O}$ ). Urea was used as source of $\mathrm{N}$, and potassium chloride as source of K. Fertilization intervals followed recommended of Teixeira et al. (2014).

Micropropagated seedlings were planted on $01 / 21 / 2012$, when they presented 5 to 6 leaves and 30 $\mathrm{cm}$ in height in $2.0 \mathrm{~m} \times 3.0 \mathrm{~m}$ spacing (1.667 plants per hectares). Cultural treatments were carried out according to Moreira (1999). 'Prata-anã' and 'BRS Platina' banana cultivars received preventive fungicide applications to control Black Sigatoka disease due to their susceptibility to the disease.

Bunches were harvested when fruits of the $2^{\text {nd }}$ bunch had diameter from 32 to $34 \mathrm{~mm}$, being referred to APTA's "Polo Regional do Vale do Ribeira" packing house for processing.

For fruit post-harvest quality analysis, two bunches were used in each replicate and only fruits from the $2^{\text {nd }}$ hand of each bunch were used, being divided into bouquets with four to six fruits each in three production cycles. Then, the bouquets were weighed and packaged in hermetically closed air-conditioning chamber of 15.6 $\mathrm{m}^{3}$ where it was applied the dose of $12.8 \mathrm{ml} \mathrm{m}^{-3}$ from the concentrated liquid Etil ${ }^{\circledR}$ inserted in the ethylene gas 
generator, in a total period of 36 hours to exposure to the gas, at the temperature of $18^{\circ} \mathrm{C} \pm 1$ and relative air humidity varying from 80 to $95 \%$. The management adopted during acclimatization was aeration, by opening the chamber's door from 12 to 12 hours for 15 minutes, and, then, the product was recharged, in order to provide fruit ripening.

After acclimatization, bouquets were kept at room temperature for fruit ripening. Fruits evaluations were performed four days after fruit removal from the chamber, when most cultivars presented at stage 6 coloring, according to Von Loesecke scale from the classification standards of the Brazilian Program For Modernization of Horticulture (PBMH; PIF, 2006). The following characteristics were evaluated: mass loss (\%) - fruit mass was considered before acclimatization and after four days; pulp firmness - determined with digital penetrometer with $8 \mathrm{~mm}$ tip, taking eight readings on opposite sides of four fruits and results were expressed in Newton $(\mathrm{N})$; peel color - determined with the colorimeter with a direct reflectance Reading of the ${ }^{\circ} \mathrm{Hue}$, taking the CIELAB method, and it was used the mean of three determinations in the longitudinal direction of the fruit; soluble solids content (SS) - determined with an aliquot of four crushed fruits filtered in gaze and measured with digital manual refractometer ( $\left.{ }^{\circ} \mathrm{Brix}\right) ; \mathrm{pH}$ and titratable acidity (TA) - determined according to I.A.L. (1985); and SS/TA ratio: calculated based on the SS and TA results.

Data were submitted to analysis of variance and F-test, and when significant for the quantitative variable (fertilizations), it was adjusted to obtain regression equations and when only significant for qualitative variables (cultivar and cycle), averages were compared by the Tukey test at $5 \%$ probability through the SISVAR statistical package (FERREIRA, 2011).

\section{Results and discussion}

Table 1 shows the averages of chemical, soil and nutritional attributes of banana cultivars. It was observed that most results are within adequate levels for the development of banana trees, except for organic matter and soil manganese content and leaf phosphorus, potassium and zinc levels. Although the leaf K content was below adequate levels at all fertilization levels, increasing fertilizer doses provided increased fruit development and yield.

Fruits mass loss during banana ripening is variable according to the different banana cultivars, as observed in this study for 'Prata' banana cultivar. In variance analysis, there wasn't significance for the quantitative variable (fertilization levels), but there were differences in the average of cultivars and production cycles. 'PA94-01' cultivar presented lower mass loss percentage, regardless of fertilization level and production cycle in which it was evaluated (Table 2). Th lower mass loss observed is possibly due to the genotypic inheritance of this cultivar, because each specie or cultivar has a characteristic respiration and transpiration process under normal conditions (WILLS et al., 1998). In the transpiration process, water loss of fruit tissues occurs in the form of water vapor, originated from intercellular spaces; in a lower degree, water loss occurs in respiration, during $\mathrm{CO}_{2}$ and water formation (CANTILLANO, 1991). Castricini et al. (2015) observed a reduction in fresh mass of $6.7 \%$ in 'Prata-Anã' and $18.3 \%$ in 'BRS Platina' cultivars in the same ripening stage, and these values were different from those found in this study, possibly due to differences in the environmental conditions and in the ripening stage of fruits at harvest time.

Another important characteristic to determine the quality of bananas for market is peel color. Pel color is a referential, with a certain degree of precision, of the fruit's ripening stage (CHITARRA; CHITARRA, 2005). For this, the Hue angle was used, because it is the parameter that best expresses the change in peel color during fruit ripening, from green $\left(180^{\circ}\right)$ until reaching the yellow color $\left(90^{\circ}\right)$ (AZZOLINI et al., 2004). Thus, it was observed for 'Prata' banana cultivars that there was no significant effect of fertilization levels on the analysis of variance. Differences were found only between cultivars and production cycles, and 'BRS Platina' cultivar presented less intense yellow coloration, represented by the highest ${ }^{\circ}$ Hue value (Table 2). The most suitable angular range of yellow coloration for banana peel comprises between 85 and $90^{\circ}$, found in cvs. Prata-Anã and PA94-01 (Table 2).

During fruit ripening, ethylene produced by the fruit and applied in acclimatization can influence chlorophyll degradation on fruit peel, concomitantly turning carotenoids visible (CASTRICINI et al., 2015). According to MAPA (2015), the peel color of 'Prata' banana is classified as medium yellow, which was not observed for 'BRS Platina' cultivar, presenting greenish yellow peel, similar to bananas from the Cavendish subgroup (MAPA, 2015), which are less attractive to the consumer market.

The effects of nitrogen and potassium fertilization on banana peel were not found in literature; however, it is assumed that well-nourished plants, especially with $\mathrm{N}$ and $\mathrm{Mg}$, present higher chlorophyll contents in the peel, since these nutrients are part of its structure (MALAVOLTA et al., 1997). As a result, during the ripening process of banana, part of chlorophyll present in the peel may not be completely degraded, not allowing yellow color pigments (especially carotenoids) to become visible, represented by Hue values greater than $90^{\circ}$ in 'BRS Platina' cultivar.

Another physical change occurring during banana ripening is the loss of pulp firmness. It was observed in this study that there were differences between cultivars and production cycles. It was observed in Table 2 that 'PrataAnã' cultivar presented greater pulp firmness compared 
to the other cultivars $(5.0 \mathrm{~N})$, regardless of fertilization level and production cycle. These results are in agreement with those obtained in studies by Oliveira et al. (2013) and Pimentel et al. (2010), who observed that 'BRS Platina' cultivar presented lower pulp firmness compared to 'PrataAnã' cultivar, which is an intrinsic characteristic of the cultivar and depends on the fruit ripening stage (RIBEIRO, 2006). In fruits with less advanced ripening stage, cell wall integrity is higher, and when kept at low temperatures, the action of enzymes responsible for pulp softening is lower, because the autocatalytic capacity and sensitivity to ethylene decreases, causing reduction on the activation of several enzymes responsible for tissue transformations (CHITARRA; CHITARA, 2005). Although the harvest diameter was defined, clusters were harvested at different times of the year, due to differences in the production cycle of each cultivar, influenced by genotypic characteristics and fertilization levels, which may have caused differences among production cycles for pulp firmness.

During banana ripening, transformations and changes occur in the starch, sugar, tannin contents and acidity (CHITARRA; CHITARRA, 2005). In this study, there was no significant effect of fertilization levels on post-harvest chemical characteristics of banana cultivars. Possibly, there was no effect of nitrogen and potassium fertilization due to the low response to physicochemical characteristics of the banana pulp and strongly influenced by the genetic inheritance of the cultivars evaluated in this experiment, corroborating with Aular and Natale (2013) whose related that post harvesting banana characteristics are few influenced by fertilization, whereas climatic conditions exert a more striking effect, corroborating with the results of the nutritional state of the plants, since there were no differences in the $\mathrm{N}$ and $\mathrm{K}$ foliar contents among the cultivars and fertilization levels (Table 1), but the K presented below the adequate level for the production.

There are literature reports about the effects of $\mathrm{N}$ and $\mathrm{K}$ fertilization on banana trees and about post-harvest characteristics, which are controversial and specific for each cultivar. Pinto et al. (2005) observed that the maximum SS/TA ratio was reached for 'Pacovan' banana fruits with the highest $\mathrm{N}$ and $\mathrm{K}$ doses $\left(600 \mathrm{~kg} \mathrm{ha}^{-1}\right.$ of both). With the same cultivar, Weber et al. (2006) observed that pulp SS and TA were affected by nitrogen and potassium fertilization. Costa (2011) observed that the increase of $\mathrm{K}$ doses did not influenced $\mathrm{pH}, \mathrm{SS}$ and TA values in the pulp of 'Galil 18' banana cultivar (Prata type). Guerra et al. (2004) evaluated the effect of the frequency of nitrogen and potassium fertigation on 'Prata-anã' fruits and observed that the increase in $\mathrm{N}$ and $\mathrm{K}$ doses did not influenced SS, TA and $\mathrm{pH}$ content in both production cycles. The same occurred in this study, which leads to the assumption that other factors may influence the post-harvest chemical characteristics of banana, such as environment (climate and soil), genetic and management.
Differences were observed between cultivars and production cycles for all chemical characteristics evaluated. 'Prata-Anã' cultivar presented higher SS content and lower TA values than the other cultivars (Tables 3 and 4), regardless of fertilization levels and production cycles, reflecting in the highest SS/TA ratio.

'PA94-01' cultivar presented the lowest SS and $\mathrm{pH}$ values, and consequently the highest TA value, as well as lower SS/TA ratio compared to the other cultivars (Tables 3 and 4). The differences among cultivars may be related to the higher or lower starch content accumulated in fruits. The chemical characteristics of banana pulp varied according to starch transformations that occur during the ripening process in the different cultivars (JESUS et al., 2004). Since banana is a climacteric fruit, there is a significant increase in the respiration rate on the first days after ethylene treatment, and differences in pulp acidity among cultivars may be linked to the respiratory metabolism (ETIENNE et al., 2013), more exactly to the tricarboxylic acid metabolism (Krebs cycle) during the ripening process, increasing the sugar/acid ratio (CHITARRA; CHITARRA, 2005). Therefore, in the PA9401 cultivar, possibly in the Krebs cycle, there is higher production of tricarboxylic acid, increasing pulp acidity and reflecting in higher titratable acidity and reducing the $\mathrm{SS}$ and TA ratio.

'BRS Platina' cultivar presented lower SS content (Table 3) when compared to 'Prata-Anã' cultivar, and consequently, lower SS/TA ratio (Tables 3 and 4). Oliveira et al. (2013) evaluated the acceptance level of bananas cultivars and found that although 'BRS Platina' is a hybrid of 'Prata-Anã' cultivar, it presents sensory characteristics that refers to 'Nanica' fruits at the end of the ripening process (stage 7), according to observations performed by some tasters. The same authors reported that possibly there was a higher inheritance of the male parent (M53), which comes from the diploid specie (AA) from $M$. acuminata. Therefore, 'BRS Platina' cultivar needs further research to minimize sensory and color differences (Tables 2 and 3) from its mother plant (PrataAnã), as for example, harvesting at lower ripening stage, in addition to different ethylene doses and exposure time to the gas, as well as temperature and humidity inside the acclimatization chamber.

Silva et al. (2002) reported that the flavor of hybrid fruits is not always identical to that of their respective parents, which could cause rejection by consumers. Besides flavor, the size and fruits appearance of new genotypes may be similar to the corresponding cultivars, and it may be considered in banana genetic breeding and in the acceptance by consumers (OLIVEIRA et al., 2013).

Despite differences in the physicochemical characteristics of tolerant and/or resistant 'Prata' cultivars, the evaluated cultivars have great potential of insertion in the consumer marked due to their agronomic 
and environmental advantages, both for producers and consumers, such as reduction in the use of agrochemicals and consequently lower production cost and lower risk of environmental contamination and fruits free from chemical products. In addition, the consumption of fresh banana in Brazil is very large, and there is preference for a certain type of banana and even for a particular cultivar. The preference of the metropolitan region of São Paulo is for 'Nanica' cultivar, while the largest 'Prata' cultivar market is concentrated in the Southern region of Brazil, especially in the state of Rio Grande do Sul. Therefore, there is need for several adjustments in the acclimatization process for the different banana cultivars, as well as in the cultural management to achieve the sensory quality to supply market demands. The launching of new cultivars and the introduction in production areas may be preceded by specific studies within the breeding program, as it is being done with the cv. PA94-01, which has not been launched yet by EMBRAPA to carry out the

characterization of post-harvest studies and the acceptance in the different consumer markets of Brazil.

Table 1- Average nutrient content in soil and leaf of cultivars and production cycles, Pariquera-Açu, SP, 2016.

\begin{tabular}{|c|c|c|c|c|c|c|c|c|c|c|c|}
\hline \multicolumn{12}{|c|}{ Soil chemical attributes } \\
\hline \multirow{2}{*}{ Cultivars } & O.M. & $\mathrm{P}$ & $\mathrm{K}$ & $\mathrm{Ca}$ & $\mathrm{Mg}$ & B & $\mathrm{Cu}$ & $\mathrm{Fe}$ & $\mathrm{Mn}$ & $\mathrm{Zn}$ & \\
\hline & $\mathrm{g} \mathrm{dm}^{-3}$ & $m g \mathrm{dm}^{-3}$ & \multicolumn{3}{|c|}{------'mmol $\mathrm{dm}^{-3}------$} & \multicolumn{6}{|c|}{ 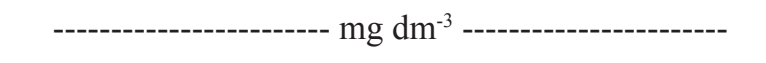 } \\
\hline PA94-01 & 21 & 15 & 4.1 & 18 & 5.1 & 0.57 & 0.20 & 188 & 1.3 & \multicolumn{2}{|l|}{2.2} \\
\hline Prata Anã & 21 & 16 & 2.5 & 21 & 5.9 & 0.67 & 0.32 & 186 & 1.6 & \multicolumn{2}{|c|}{3,5} \\
\hline BRS Platina & 22 & 17 & 4.2 & 21 & 8.1 & 0.55 & 0.33 & 181 & 1.3 & \multicolumn{2}{|c|}{2.2} \\
\hline $1^{\circ}$ cycle & 23 & 8 & 1.5 & 22 & 9.1 & 0.80 & 0.28 & 183 & 1.6 & \multicolumn{2}{|l|}{3.3} \\
\hline $2^{\circ}$ cycle & 19 & 24 & 5.7 & 18 & 3.7 & 0.40 & 0.29 & 187 & 1.2 & \multicolumn{2}{|c|}{1.9} \\
\hline $\begin{array}{c}\text { Averages } \\
\text { (Cvs. e cycles) } \\
\end{array}$ & 21 & 16 & 3.6 & 20 & 6.4 & 0.60 & 0.29 & 185 & 1.4 & \multicolumn{2}{|l|}{2.6} \\
\hline Suitable levels* & $26-50$ & $16-40$ & $1.0-1.8$ & $12-24$ & $4.6-9.0$ & $0.2-0.6$ & $0.8-1.2$ & $19-30$ & $6.0-8.0$ & \multicolumn{2}{|c|}{$1.0-1.5$} \\
\hline \multicolumn{12}{|c|}{ Nutritional status of plants } \\
\hline Cultivars & $\mathrm{N}$ & $\mathrm{P}$ & $\mathrm{K}$ & $\mathrm{Ca}$ & $\mathrm{Mg}$ & $\mathrm{S}$ & $\mathrm{B}$ & $\mathrm{Cu}$ & $\mathrm{Fe}$ & $\mathrm{Mn}$ & $\mathrm{Zn}$ \\
\hline PA94-01 & 33 & 1.9 & 25 & 9.1 & 3.0 & 2.3 & 18 & 6.0 & 84 & 190 & 10 \\
\hline Prata Anã & 33 & 1.8 & 21 & 9.8 & 3.8 & 2.2 & 14 & 5.2 & 80 & 245 & 10 \\
\hline BRS Platina & 32 & 1.7 & 20 & 9.1 & 3.4 & 2.2 & 15 & 9.1 & 98 & 238 & 11 \\
\hline $1^{\circ}$ cycle & 34 & 1.7 & 22 & 9.8 & 3.5 & 2.2 & 15 & 5.4 & 70 & 214 & 10 \\
\hline $2^{\circ}$ cycle & 31 & 1.8 & 22 & 8.9 & 3.3 & 2.2 & 16 & 8.2 & 105 & 235 & 11 \\
\hline $\begin{array}{c}\text { Averages } \\
\text { (cultivars and cycles) }\end{array}$ & 32 & 1.8 & 22 & 9.3 & 3.4 & 2.2 & 16 & 6.8 & 87 & 224 & 10 \\
\hline Suitable levels* & $27-36$ & $1.8-2.7$ & $35-54$ & $2.5-12$ & $3.0-6.0$ & $2.0-3.0$ & $10-25$ & $3.0-30$ & $80-360$ & $200-2000$ & $20-50$ \\
\hline
\end{tabular}

*Malavolta et al. (1997) 
Table 2- Average mass loss and peel color percentage ('Hue) of 'Prata-Anã', 'BRS Platina' and 'PA94-01' banana cultivars with increasing $\mathrm{N}$ and $\mathrm{K}$ doses $\left(50 \%: 175 \mathrm{~N}+285 \mathrm{~K}_{2} \mathrm{O} ; 100 \%: 350 \mathrm{~N}+570 \mathrm{~K}_{2} \mathrm{O}\right.$ and $150 \%: 525 \mathrm{~N}+855$ $\mathrm{K}_{2} \mathrm{O}$, in $\mathrm{Kg} \mathrm{ha}^{-1}$ year $^{-1}$ ) in three production cycles, Pariquera-Açu, SP, 2016. 1st and the 2nd

\begin{tabular}{|c|c|c|c|c|c|c|c|c|}
\hline \multicolumn{9}{|c|}{ Mass loss percentage } \\
\hline \multirow{2}{*}{ Cultivars $(\mathrm{Cv})$} & \multicolumn{4}{|c|}{ Fertilization levels - FL (\%) } & \multicolumn{3}{|c|}{ Cycles (C) } & \multirow{2}{*}{$\begin{array}{l}\text { Averages } \\
\text { (FL and C) }\end{array}$} \\
\hline & 0 & 50 & 100 & 150 & $1^{\text {st }}$ & $2^{\text {nd }}$ & $3^{\text {rd }}$ & \\
\hline PA94-01 & $7.0 \mathrm{a}$ & 8.5 & 8.0 & 8.8 & 8.4 & $7.5 \mathrm{a}$ & 8.4 & $8.1 \mathrm{a}$ \\
\hline Prata-Anã & $10.1 \mathrm{ab}$ & 10.8 & 10.7 & 9.9 & 11.5 & $10.3 \mathrm{ab}$ & 9.3 & $10.4 \mathrm{~b}$ \\
\hline BRS Platina & $10.3 \mathrm{~b}$ & 10.0 & 8.9 & 13.2 & 9.9 & $13.0 \mathrm{~b}$ & 8.9 & $10.6 \mathrm{~b}$ \\
\hline Averages & 9.1 & 9.8 & 9.2 & 10.6 & 9.9 & 10.3 & 8.9 & \\
\hline $\begin{array}{c}\text { CV1\% } \\
\text { (Cv x FL) }\end{array}$ & \multicolumn{8}{|c|}{14.0} \\
\hline $\begin{array}{c}\mathrm{CV} 2 \% \\
(\mathrm{C} \times \mathrm{CV} \times \mathrm{FL}) \\
\end{array}$ & \multicolumn{8}{|c|}{15,6} \\
\hline \multicolumn{9}{|c|}{${ }^{\circ} \mathrm{Hue}$} \\
\hline Cultivars $(\mathrm{Cy})$ & \multicolumn{4}{|c|}{ Fertilization levels - FL (\%) } & \multicolumn{3}{|c|}{ Cycles (C) } & \multirow{2}{*}{$\begin{array}{l}\text { Averages } \\
\text { (FL and C) }\end{array}$} \\
\hline Cuilivals (CV) & 0 & 50 & 100 & 150 & $1^{\text {st }}$ & $2^{\text {nd }}$ & $3^{\text {rd }}$ & \\
\hline PA94-01 & $89.5 \mathrm{a}$ & 89.1 & 88.4 a & $89.5 \mathrm{a}$ & 88.4 a & $89.0 \mathrm{a}$ & 89.6 a & 89.1 a \\
\hline Prata-Anã & $87.5 \mathrm{a}$ & 89.8 & $90.0 \mathrm{a}$ & 89.6 a & 88.8 a & $89.0 \mathrm{a}$ & $90.2 \mathrm{a}$ & $89.2 \mathrm{a}$ \\
\hline BRS Platina & $95.8 \mathrm{~b}$ & 91.8 & $96.0 \mathrm{~b}$ & $96.0 \mathrm{~b}$ & $95.2 \mathrm{~b}$ & $95.0 \mathrm{~b}$ & $94.9 \mathrm{~b}$ & $94.9 \mathrm{~b}$ \\
\hline Averages & 91.0 & 90.2 & 91.5 & 91.7 & 90.8 & 91.0 & 91.5 & \\
\hline $\begin{array}{c}\text { CV1\% } \\
(\mathrm{Cv} \times \mathrm{FL})\end{array}$ & \multicolumn{8}{|c|}{3.7} \\
\hline $\begin{array}{c}\mathrm{CV} 2 \% \\
(\mathrm{C} \times \mathrm{CV} \times \mathrm{FL}) \\
\end{array}$ & \multicolumn{8}{|c|}{3.7} \\
\hline
\end{tabular}

Firmness (N)

\begin{tabular}{|c|c|c|c|c|c|c|c|c|}
\hline \multirow{2}{*}{ Cultivars $(\mathrm{Cv})$} & \multicolumn{4}{|c|}{ Fertilization levels - FL (\%) } & \multicolumn{3}{|c|}{ Cycles (C) } & \multirow{2}{*}{$\begin{array}{l}\text { Averages } \\
\text { (FL and C) }\end{array}$} \\
\hline & 0 & 50 & 100 & 150 & $1^{\text {st }}$ & $2^{\text {nd }}$ & $3^{\text {rd }}$ & \\
\hline PA94-01 & $5.2 \mathrm{~b}$ & 4.6 & $4.5 \mathrm{ab}$ & $4.3 \mathrm{a}$ & $4.2 \mathrm{a} \mathrm{A}$ & $4.3 \mathrm{~A}$ & 5.2 a B & 4.5 \\
\hline
\end{tabular}

\begin{tabular}{|c|c|c|c|c|c|c|c|c|c|}
\hline Prata-Anã & $4.8 \mathrm{ab}$ & 4.8 & $4.8 \mathrm{~b}$ & $5.1 \mathrm{~b}$ & $5.0 \mathrm{~b} \mathrm{~B}$ & $4.2 \mathrm{~A}$ & 5.8 & b C & $5.0 \mathrm{~b}$ \\
\hline BRS Platina & $4.3 \mathrm{a}$ & 4.3 & $4.1 \mathrm{a}$ & $4.4 \mathrm{a}$ & 3.9 a A & $4.1 \mathrm{~A}$ & 4.9 & a B & $4.3 \mathrm{a}$ \\
\hline Averages & 4.8 & 4.6 & 4.5 & 4.6 & $4.3 \mathrm{~A}$ & $4.2 \mathrm{~A}$ & 5.3 & B & \\
\hline $\begin{array}{c}\text { CV1\% } \\
\text { (Cv x FL) } \\
\end{array}$ & \multicolumn{9}{|c|}{11.2} \\
\hline $\begin{array}{c}\mathrm{CV} 2 \% \\
(\mathrm{C} \times \mathrm{CV} \times \mathrm{FL})\end{array}$ & \multicolumn{9}{|c|}{12.3} \\
\hline
\end{tabular}

*Averages followed by different lowercase letters between cultivars (columns) and uppercase between fertilization levels and production cycles (lines) differ by the Tukey Test $(\mathrm{p}<0.05)$. 
Table 3- Average $\mathrm{pH}$ and Soluble solids in the pulp of 'Prata-Anã', 'BRS Platina' and 'PA94-01' banana cultivars with increasing $\mathrm{N}$ and $\mathrm{K}$ doses $\left(50 \%: 175 \mathrm{~N}+285 \mathrm{~K}_{2} \mathrm{O} ; 100 \%: 350 \mathrm{~N}+570 \mathrm{~K}_{2} \mathrm{O}\right.$ and $150 \%: 525 \mathrm{~N}+855 \mathrm{~K}_{2} \mathrm{O}$, in $\mathrm{Kg} \mathrm{ha}^{-1}$ year $^{-1}$ ) in three production cycles, Pariquera-Açu, SP, 2016.

$\mathrm{pH}$

\begin{tabular}{|c|c|c|c|c|c|c|c|c|c|}
\hline \multirow{2}{*}{ Cultivars $(\mathrm{Cv})$} & \multicolumn{5}{|c|}{ Fertilization levels - FL (\%) } & \multicolumn{3}{|c|}{ Cycles (C) } & \multirow{2}{*}{$\begin{array}{l}\text { Averages } \\
\text { (FL and C) }\end{array}$} \\
\hline & 0 & 50 & 100 & 150 & & $1^{\text {st }}$ & $2^{\text {nd }}$ & $3^{\text {rd }}$ & \\
\hline PA94-01 & $3.8 \mathrm{~b}$ & $4.0 \mathrm{~b}$ & $4.0 \mathrm{~b}$ & 4.0 & $\mathrm{~b}$ & $4.1 \mathrm{~b} \mathrm{~A}$ & $4.0 \mathrm{~b} \mathrm{~A}$ & $3.8 \mathrm{~b} \mathrm{~B}$ & $4.0 \mathrm{~b}$ \\
\hline Prata-Anã & $4.3 \mathrm{a}$ & $4.4 \mathrm{a}$ & $4.4 \mathrm{a}$ & 4.5 & $\mathrm{a}$ & 4.5 a $\mathrm{A}$ & 4.4 a $\mathrm{AB}$ & 4.3 a B & $4.4 \mathrm{a}$ \\
\hline BRS Platina & $4.4 \mathrm{a}$ & $4.5 \mathrm{a}$ & $4.4 \mathrm{a}$ & 4.4 & $\mathrm{a}$ & 4.9 a $\mathrm{A}$ & 4.5 a A & 4.3 a B & $4.5 \mathrm{a}$ \\
\hline Averages & 4.2 & 4.3 & 4.3 & 4.3 & & $4.4 \mathrm{~A}$ & $4.3 \mathrm{~B}$ & $4.1 \mathrm{C}$ & \\
\hline $\begin{array}{c}\text { CV } 1 \% \\
(\mathrm{Cv} \times \mathrm{FL})\end{array}$ & & & & & 4,2 & & & & \\
\hline $\begin{array}{c}\mathrm{CV} 2 \% \\
(\mathrm{C} \times \mathrm{CV} \times \mathrm{FL})\end{array}$ & & & & & 3,9 & & & & \\
\hline
\end{tabular}

Soluble Solids ( ${ }^{\circ}$ Brix $)$

\begin{tabular}{|c|c|c|c|c|c|c|c|c|c|}
\hline \multirow{2}{*}{ Cultivars $(\mathrm{Cv})$} & \multicolumn{5}{|c|}{ Fertilization levels - FL (\%) } & \multicolumn{3}{|c|}{ Cycles (C) } & \multirow{2}{*}{$\begin{array}{l}\text { Averages } \\
\text { (FL and C) }\end{array}$} \\
\hline & 0 & 50 & 100 & 150 & & $1^{\text {st }}$ & $2^{\text {nd }}$ & $3^{\text {rd }}$ & \\
\hline PA94-01 & $22.8 \mathrm{~b}$ & $22.9 \mathrm{~b}$ & $22.4 \mathrm{c}$ & 22.8 & $\mathrm{~b}$ & $23.4 \mathrm{~b}$ & $22.4 \mathrm{c}$ & $22.4 \mathrm{~b}$ & $22.7 \mathrm{c}$ \\
\hline Prata-Anã & $28.0 \mathrm{a}$ & $28.2 \mathrm{a}$ & $28.2 \mathrm{a}$ & 27.7 & $\mathrm{a}$ & 29.0 a A & 28.1 a $\mathrm{AB}$ & 27.0 a B & 28.0 a \\
\hline BRS Platina & $23.7 \mathrm{~b}$ & $23.8 \mathrm{~b}$ & $24.3 \mathrm{~b}$ & 23.7 & $\mathrm{~b}$ & $24.3 \mathrm{~b} \mathrm{~A}$ & $24.6 \mathrm{~b} \mathrm{~A}$ & 22.7 b B & $23.9 \mathrm{~b}$ \\
\hline Averages & 24.8 & 24.9 & 25.0 & 24.8 & & $25.6 \mathrm{~A}$ & $25.0 \mathrm{~A}$ & $24.1 \mathrm{~B}$ & \\
\hline $\begin{array}{c}\mathrm{CV} 1 \% \\
(\mathrm{Cv} \times \mathrm{FL})\end{array}$ & & & & & 3.8 & & & & \\
\hline $\begin{array}{c}\mathrm{CV} 2 \% \\
(\mathrm{C} \times \mathrm{CV} \times \mathrm{FL})\end{array}$ & & & & & 4.6 & & & & \\
\hline
\end{tabular}

*Averages followed by different lowercase letters between cultivars (columns) and uppercase between production cycles (lines) differ by the Tukey Test $(\mathrm{p}<0.05)$. 
Table 4. Average Titratable acidity and SS/TA ratio in the pulp of 'Prata-Anã', 'BRS Platina' and 'PA94-01' banana cultivars with increasing $\mathrm{N}$ and $\mathrm{K}$ doses $\left(50 \%: 175 \mathrm{~N}+285 \mathrm{~K}_{2} \mathrm{O} ; 100 \%: 350 \mathrm{~N}+570 \mathrm{~K}_{2} \mathrm{O}\right.$ and $150 \%: 525 \mathrm{~N}+855$ $\mathrm{K}_{2} \mathrm{O}$, in $\mathrm{Kg} \mathrm{ha}^{-1}$ year $^{-1}$ ) in three production cycles, Pariquera-Açu, SP, 2016.

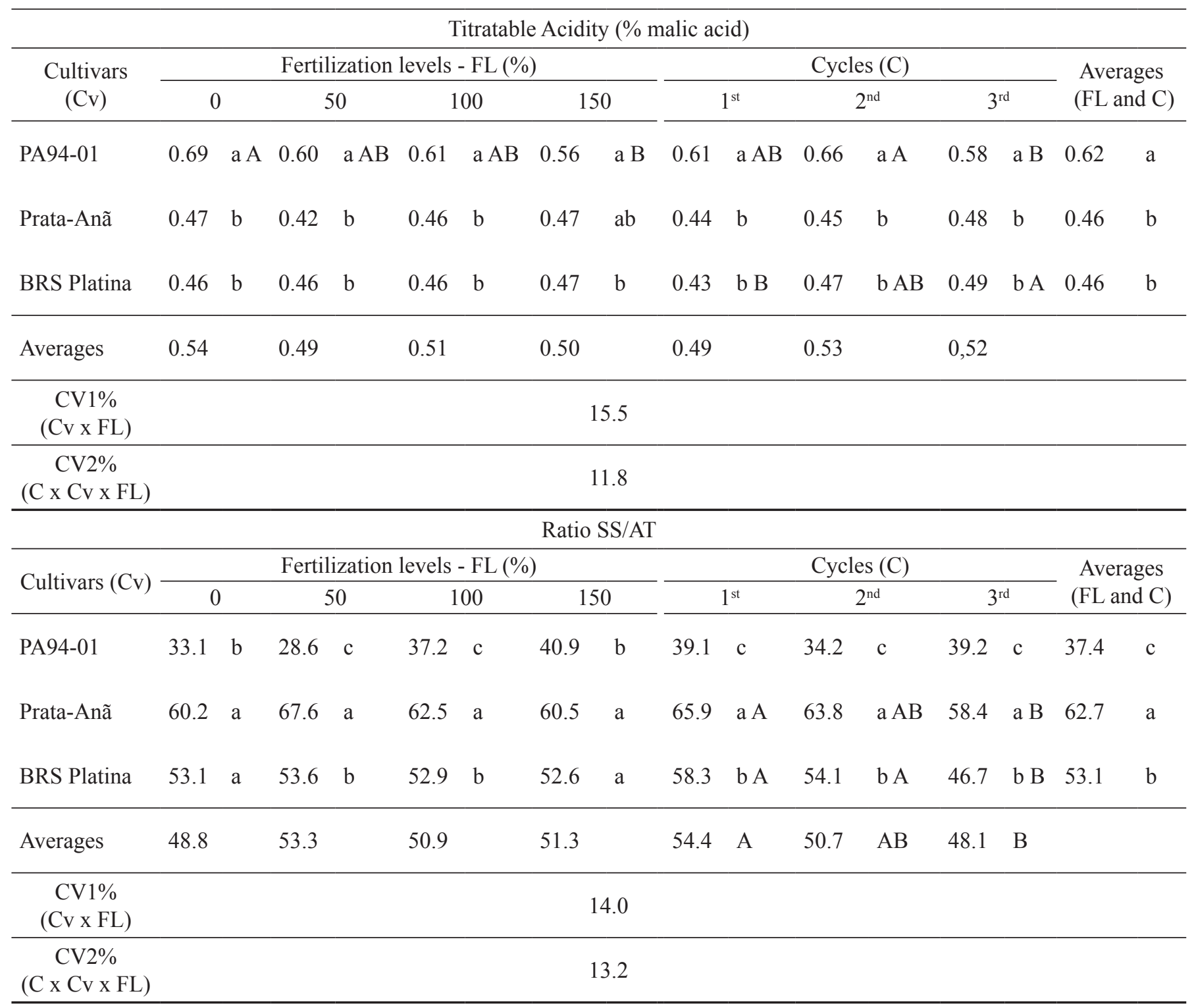

Averages followed by different lowercase letters between cultivars (columns) and uppercase between fertilization levels and production cycles (lines) differ by the Tukey Test $(\mathrm{p}<0.05)$

\section{Conclusions}

The application of $\mathrm{N}$ and $\mathrm{K}$ does did not influence the post-harvest physicochemical characteristics of 'PrataAnã', 'BRS Platina' and 'PA94-01' cultivars.

Regardless of $\mathrm{N}$ and $\mathrm{K}$ doses, 'Prata-Anã', 'BRS Platina' and 'PA94-01' banana cultivars presented differences among themselves in the post-harvest physicochemical characteristics.

\section{Acknowledgments}

To the "Fundação de Apoio à Pesquisa do Estado de São Paulo" (FAPESP - Proc. n. 2012/50820-1) and to "Embrapa Mandioca e Fruticultura" (MP2 - Project MelhorMusa) for financial support and to CAPES/CNPq for granting the doctoral scholarship to the first author. 


\section{References}

AULAR, J.; NATALE, W. Nutrição mineral e qualidade do fruto de algumas frutíferas tropicais: goiabeira, mangueira, bananeira e mamoeiro. Revista Brasileira de Fruticultura, Jaboticabal, v.35, n.4, p.1214-1231, 2013.

AZZOLINI, M.; JACOMINO, A.P.; BRON, I.U. Índices para avaliar qualidade pós-colheita de goiabas em diferentes estádios de maturação. Pesquisa Agropecuária Brasileira, Brasília, DF, v.39, n.2, p.139-145, 2004.

CANTILLANO, R.F.F. Armazenamento refrigerado de frutas e hortaliças: importância da transpiração. Horti Sul, Pelotas, v. 1, n. 4, p. 23-31, 1991.

CASTRICINI, A.; SANTOS, L.O.; DELIZA, R.; COELHO, E.F.; RODRIGUES, M.G.V. Caracterização pós-colheita e sensorial de genótipos de bananeiras tipo Prata. Revista Brasileira de Fruticultura, Jaboticabal, v.37, n.1, p.027-037, 2015.

ChITARRA, M.I.F.; CHITARRA, A.B. Pós-colheita de frutos e hortaliças: fisiologia e manuseio. 2.ed. Lavras: UFLA, 2005. 785p.

COSTA, F. da S. Variáveis de crescimento, produção e qualidade de frutos da bananeira 'Galil 18' (Musa spp., $\mathrm{AA} A B$ ) sob níveis de água e de potássio em tabuleiro costeiro. 2011. Dissertação (Mestrado em Ciências Agrárias) - Universidade Federal do Recôncavo da Bahia, Cruz das Almas, 2011.

ETIENNE, A.; GÉNARD, M.; BANCEL, D.; BENOIT, S.; BUGAUD, C. A model approach revealed the relationship between banana pulp acidity and composition during growth and postharvest ripening. Scientia Horticulturae, Amsterdam, v.162, p.125-134, 2013.

FERREIRA, D.F. SISVAR: a computer statistical analysis system. Ciência e Agrotecnologia, Lavras, v.35, n.6, p.1039-1042, 2011.

GUERRA, A.G.; ZANINI, J.R.; NATALE, W.; PAVANI, L.C. Frequência da fertirrigação da bananeira Prata-Anã com nitrogênio e potássio aplicados por microaspersão. Engenharia Agrícola, Jaboticabal, v.24, n.1, p.80-88, 2004.

IAL - INSTITUTO ADOLFO LUTZ. Normas analíticas: métodos químicos e físicos para a análise de alimentos. 2.ed. São Paulo:IAL, 1985. v.1, 371p.
JESUS, S. C. de; FOLEGATTI, M. I. da S.; MATSUURA, F. C. A. U.; CARDOSO, R. L. Caracterização física e química de frutos de diferentes genótipos de bananeira. Bragantia, Campinas, v.63, n.3, p.315-323, 2004.

MALAVOLTA, E.; VITTI, G.C.; OLIVEIRA, S.A. de. Princípios, métodos e técnicas de avaliação do estado nutricional. In: MALAVOLTA, E.; VITTI, G.C.; OLIVEIRA, S.A. de (ed.). Avaliação do estado nutricional das plantas: princípios e aplicações. 2.ed. rev. e atual. Piracicaba: POTAFOS, 1997. p.115-230.

MAPA - Ministério da Agricultura, Pecuária e Abastecimento. Proteção de cultivares. Disponível $\mathrm{em}$ : http://www.agricultura.gov.br/vegetal/registrosautorizacoes/protecao-cultivares/formularios-protecaocultivares. Acesso em: 06 jan. 2016.

MOREIRA, R.S. Banana: teoria e prática de cultivo. 2.ed. Campinas: Fundação Cargill, 1999. 335p. CD-ROM

NOMURA E.S.; MORAES, W.da S.; DAMATTO JUNIOR, E.R.; FUZITANI, E.J.; SAES, L.A.; AMORIM, E.P.; SILVA, S.O. Evaluation of banana genotypes over two crop cycles under subtropical conditions in the Ribeira Valley, São Paulo, Brazil. Acta Horticulturae, Leuven, v. 986, p.61-70, 2013.

OLIVEIRA, C.G de; SÉRGIO DONATO, L.R.; MIZOBUTSI, G.P.; SILVA, J.M. da; MIZOBUTSI, É.H. Características pós-colheita de bananas 'Prata-Anã' e 'BRS Platina' armazenadas sob refrigeração. Revista Brasileira de Fruticultura, Jaboticabal, v.35, n.3, p.891897, 2013.

PBMH \& PIF - Programa Brasileiro para a Modernização da Horticultura \& Produção Integrada de Frutas. Normas de classificação de banana. São Paulo: CEAGESP, 2006. (Documentos, 29).

PIMENTEL, R. M. de A.; GUIMARÃES, R. N.; SANTOS, V. M. dos; RESENDE, J. C. F. de. Qualidade pós-colheita dos genótipos de banana PA42-44 e PrataAnã cultivados no Norte de Minas Gerais. Revista Brasileira de Fruticultura, Jaboticabal, v.32, n.2, p.407413, 2010.

PINTO, J. M.; FARIA, M. B. de; SILVA, D. J.; FEITOSA FILHO, J. C. Doses de nitrogênio e potássio aplicadas via fertirrigação em bananeira. Irriga, Botucatu, v.10, n.1, p.46-52, 2005. 
RIBEIRO, D.M. Evolução das propriedades físicas, reológicas e químicas durante o amadurecimento da banana Prata-anã. 2006. Tese (Doutorado) Universidade Federal Viçosa, Viçosa, 2006.

SILVA, S. de O.; FLORES, J.C. de O.; LIMA NETO, F.P. Avaliação de cultivares e híbridos de bananeira em quatro ciclos de produção. Pesquisa Agropecuária Brasileira, Brasília, DF, v.37, n.11, p.1.567-1.574, 2002.

SILVA, S. de O.; ALVES, E.J.; SHEPHERD, K.; DANTAS, Z.L.L. Cultivares. In: ALVES, E.J. (org.). A cultura da banana: aspectos técnicos, socioeconômicos e agroindustriais. 2.ed. Brasília: Embrapa-SPI; Cruz das Almas: Embrapa-CNPMF, 1999. p.85-105.

TEIXEIRA, L.A.J.; NOMURA, E.S.; DAMATTO JUNIOR, E.R.; FUZITANI, E.J. Banana. In: AGUIAR, A.T.E.; GONÇALVES, C.; PATERNIANI, M.E.A.G.; TUCCI, M.G.S.; CASTRO, C.E.F. (ed.). Instruções Agrícolas para as principais culturas econômicas. 7. ed. rev. Campinas: Instituto Agronômico, 2014. p. 46-51. (Boletim Técnico, 200).
WEBER, O.; MONTENEGRO, A.; NUNES, I.; SILVA, E.; SOARES, I.; CRISÓSTOMO, L. Adubação nitrogenada e potássica em bananeira 'Pacovan' (Musa AAB, Subgrupo Prata) na chapada do Apodi, Estado do Ceará. Revista Brasileira de Fruticultura, Jaboticabal, v.28. n.1, p.154-157, 2006.

WILLS, R.; McGLASSON, B.; GRAHAM, D.; JOYCE, D. Postharvest: an introduction to the physiology $\&$ handling of fruit, vegetables $\&$ ornamentals. $4^{\text {th }} \mathrm{ed}$. Londres: CAB International, 1998. 262p. 